\title{
KAJIAN RISIKO LINGKUNGAN UNTUK PENGGUNAAN AGEN HAYATI DI BIDANG PERTANIAN
}

\section{Environmental Risk Assessment for Uses of Biological Agents for Agriculture}

\author{
Dwi Andreas Santosa \\ Departemen Ilmu Tanah dan Sumberdaya Lahan, Bagian Bioteknologi Tanah, Fakultas Pertanian, Institut \\ Pertanian Bogor, Jl. Meranti, Kampus IPB Darmaga, Bogor 16680
}

\begin{abstract}
In Indonesia, the biological agents have been widely used in the agriculture for reducing chemical fertilizers uses, for controlling plant pest and pathogens, and for increasing rate of composting process. The application of biological agents is especially important in the organic agriculture practices. The agents consist of microorganisms both fungi and bacteria, and in some extent are also viruses, that part of them are imported from other countries. Based on their characteristics, any biological agents that are released into the environment can pose potential problems to the environment or the ecology. There is a Ministerial Decree that require an environmental risk assessment (ERA) for getting a permission of an importation of biological agents. Unfortunately, there is not any guidance to conduct ERA of biological agents. This paper reviews ERA and using of the approach to do a risk assessment of biological agents that will be used in agriculture.
\end{abstract}

\section{PENDAHULUAN}

Agen hayati mulai banyak digunakan di Indonesia. Agen hayati yang saat ini diterapkan baik dalam skala terbatas maupun skala luas adalah pupuk hayati (biofertilizer), agen proteksi tanaman atau pengendali hama/penyakit hayati (biopesticides/biological control agents) dan pupuk organik (kompos) yang diperkaya mikroorganisme. Selain itu organisme hasil rekayasa genetika (genetically modified organisms) juga telah diujicobakan di Indonesia. Persyaratan untuk melakukan kajian risiko untuk agen hayati yang akan dilepas ke lingkungan dalam skala luas atau dipasarkan terdapat misalnya dalam Peraturan Menteri Pertanian (PERMENTAN No. 28/Permentan/SR.130/5/2009) (Mentan, 2009) yang mewajibkan semua produk yang mengandung mikroorganisme untuk pertanian yang didatangkan dari luar negeri harus melalui kajian risiko lingkungan. Demikian juga organisme hasil rekayasa genetika harus melalui kajian risiko lingkungan sebelum dikomersialisasikan di Indonesia (PP 21, 2005). Ditengah tuntutan peraturan tersebut, di Indonesia belum ada pedoman tentang bagaimana melakukan kajian risiko lingkungan baik secara umum maupun spesifik berdasarkan agen yang akan dikaji.

Organisme hidup baik yang diproduksi di dalam negeri maupun yang didatangkan dari luar negeri serta organisme yang mengalami rekayasa genetika memiliki potensi untuk menimbulkan akibat yang merugikan bagi lingkungan (Hilbeck and Andow, 2004; Hilbeck et al., 2006). Potensi tersebut dapat dinilai berdasarkan sifat atau karakteristik biologis organisme yang bersangkutan dalam suatu lingkungan yang baru, serta analisis terhadap risiko terkait. Persepsi terhadap adanya pengaruh merugikan sebagian dapat berasal dari informasi yang tersedia untuk organisme ataupun lingkungan yang memiliki kemiripan dengan yang akan dikaji (familiaritas), atau berdasarkan riset terarah terhadap organisme atau lingkungan sasaran (OECD, 1995).

Konsep dan pentahapan kajian risiko sangat tergantung pada subjek yang akan dikaji. Subjek kajian dapat berupa agen fisik, misalnya agen yang mengeluarkan radiasi, agen kimia yang memiliki sifat karsinogenik, ataupun agen biologis yang memiliki potensi untuk menimbulkan risiko baik bagi kesehatan maupun lingkungan. Secara umum dikenal pentahapan kajian risiko, yang tingkat kedalamnanya berbeda-beda tergantung subyek yang akan dikaji serta manusia atau lingkungan yang akan menerima risiko tersebut.

\section{KAJIAN RISIKO}

\subsection{Konsep dan Pengertian}

Teknik kajian risiko telah digunakan oleh berbagai pihak baik kalangan profesional maupun akademisi. Kajian risiko menjadi pendekatan yang umum digunakan untuk menilai masalah-masalah lingkungan yang sangat beragam sifatnya. Pendekatan tersebut telah banyak digunakan untuk menilai risiko terhadap lingkungan suatu bahan kimia tertentu, bahan yang mengeluarkan radiasi, serta risiko lingkungan pendirian suatu pabrik tertentu. Berbagai negara telah mengembangkan pedoman untuk pelaksanaan kajian risiko (EEA, 1998; NEP, 1999; US EPA, 1998; US EPA, 2004; SEPA, 2006). Kajian risiko lingkungan menjadi pendekatan terpenting untuk mengkaji kemungkinan munculnya risiko yang disebabkan oleh pelepasan agen hayati asing dan organisme hasil rekayasa genetika (genetically modified organisms). Karena begitu luasnya wilayah cakupan dari pendekatan tersebut maka definisi mengenai kajian risiko dan istilah terkait lainnya menjadi sangat penting, karena sangat banyak istilah yang memiliki makna yang berbeda-beda yang digunakan oleh berbagai kelompok ilmuwan maupun praktisi. 
Saat ini terdapat kecenderungan perubahan pendekatan dalam kebijakan dan regulasi lingkungan dari yang berdasarkan bahaya (hazard-based) menjadi berdasarkan risiko (risk-based). Pendekatan berdasarkan risiko adalah dengan cara mengevaluasi risiko aktual dari suatu isu lingkungan tertentu, sedangkan pendekatan berdasarkan bahaya adalah mengkaji potensi bahaya yang kemungkinan muncul atau tidak muncul.

Perubahan pendekatan ke arah risiko sebagian disebabkan pemahaman bahwa tidak akan pernah ada pemecahan masalah isu lingkungan yang mampu menekan risiko hinggal nol (zero risk). Dalam beberapa kasus tujuan untuk menurunkan pencemaran hingga "aman" akan memerlukan biaya yang sangat tinggi. Biaya tersebut digunakan untuk mengelola lingkungan hingga mencapai suatu standar tertentu yang barangkali tidak perlu untuk melindungi manusia dan lingkungan. Pembuat kebijakan dan regulator perlu mengembangkan strategi tertentu terkait dengan bahan berbahaya tersebut, yaitu strategi yang menggambarkan risiko "yang dapat diterima". Meskipun demikian pendekatan ini masih menimbulkan perbedaan pendapat. Kalangan yang menentang mengajukan "prinsip kehati-hatian" (precautionary principle) untuk meminimumkan pendedahan oleh bahan tersebut hingga pada tingkat "yang dapat diterima" serta menghilangkan atau menggantikan bahan-bahan berbahaya yang tidak memiliki ambang batas aman.

Banyak data dasar, bila itu tersedia, seringkali bersifat tidak pasti (uncertainty). Data-data tersebut diantaranya data mengenai toksisitas, ekotoksisitas, model pengambilan dan transpor bahan (fate and transport model), dan model pendedahan (exposure model). Bila berhadapan dengan data yang bersifat tidak pasti, maka dua pendekatan tersedia. Pertama, adalah mengasumsikan bahwa bahan atau agen tersebut tidak merusak hingga berhasil dibuktikan secara ilmiah bahwa bahan atau agen tersebut menimbulkan efek yang merugikan. Kedua, landasan yang banyak dianut di Eropa dan kemudian diadopsi di seluruh dunia melalui konvensi internasional (Protokol Cartagena) adalah prinsip kehati-hatian. Prinsip tersebut menyatakan "Tindakantindakan lingkungan harus mampu mengantisipasi, mencegah dan melawan penyebab degradasi lingkungan. Dimana ada ancaman kerusakan lingkungan yang serius dan tidak dapat balik, maka ketiadaan data ilmiah tidak dapat digunakan sebagai alasan untuk menunda tindakantindakan untuk mencegah kerusakan lingkungan (Foster et al., 2000). Pendekatan kehati-hatian akan digunakan semampu mungkin untuk menurunkan emisi agen yang potensial merusak lingkungan sebelum hubungan sebab akibat dapat dibuktikan secara imliah atau tidak. Sedangkan pendekatan berdasarkan risiko akan dikerjakan untuk mencapai level risiko "yang dapat diterima" berdasarkan hasil kajian risiko. Hasil dari kedua pendekatan tersebut bisa sangat berbeda.

Kajian risiko juga memerlukan evaluasi apakah risiko dalam prakteknya memiliki arti ke komponen lingkungan yang dipengaruhinya. Hal ini sangat tergantung apakah risiko yang sedang dikaji dapat diterima. Evaluasi risiko secara fundamental subyektif dan berdasarkan alasan tersebut banyak praktisi lebih suka untuk memisahkannya dari pentahapan pendugaan risiko yang lebih "ilmiah". Isu lain yang penting dalam kajian risiko, terutama bagi pihak yang menginginkan penilaian terhadap keputusan yang muncul dari hasil kajian risiko, adalah memisahkan antara kajian risiko dan manajemen risiko.

\subsection{Manajemen Risiko}

Metodologi kajian risiko sebelumnya didasarkan pada evaluasi pengaruhnya terhadap kesehatan manusia, tetapi setelah itu terhadap seluruh komponen lingkungan. Hasil suatu kajian risiko kadang-kadang tidak bisa diterima sepenuhnya. Hal lainnya adalah ketersediaan dan kualitas data yang dipakai dalam kajian risiko, interprestasi data dan hasil kajian, dasar dan motivasi dibalik pengambilan keputusan yang merupakan hal fundamental dalam kajian risiko, dan bagaimana memperlakukan ketidakpastian. Manajemen risiko juga dapat memunculkan beberapa silang pendapat sebagai contoh ketidakmerataan pendistribusian biaya dan manfaat risiko, metode dan validitas penilaian biaya dan manfaat, dan memasukkan sistem nilai dan persepsi yang berlaku di masyarakat ke dalam pembuatan keputusan. Risiko dapat dikelola melalui berbagai cara yaitu melalui eliminasi risiko, transfer pertanggungjawaban risiko ke perusahaan asuransi, pengambilalihan risiko oleh perusahaan atau pemerintah, dan penurunan risiko.

\subsection{Pentahapan Kajian Risiko Lingkungan}

Secara umum Kajian Risiko Lingkungan memiliki pentahapan sebagaimana yang terlihat pada Gambar 1 . Tahapan kajian risiko lingkungan dimulai dari formulasi masalah. Formulasi masalah (problem formulation) merupakan hal yang fundamental dalam kajian risiko lingkungan. Masalah harus dapat didefinisikan dan beberapa isu yang spesifik harus jelas sebelum kajian dapat dimulai.

Bahaya yang akan dipilih dalam kajian risiko lingkungan ditentukan sebagai hasil dari formulasi masalah. Identifikasi bahaya (hazard identification) merupakan tugas yang besar sehingga banyak pakar berpendapat bahwa identifikasi bahaya merupakan hal yang terpisah dari kajian risiko. 


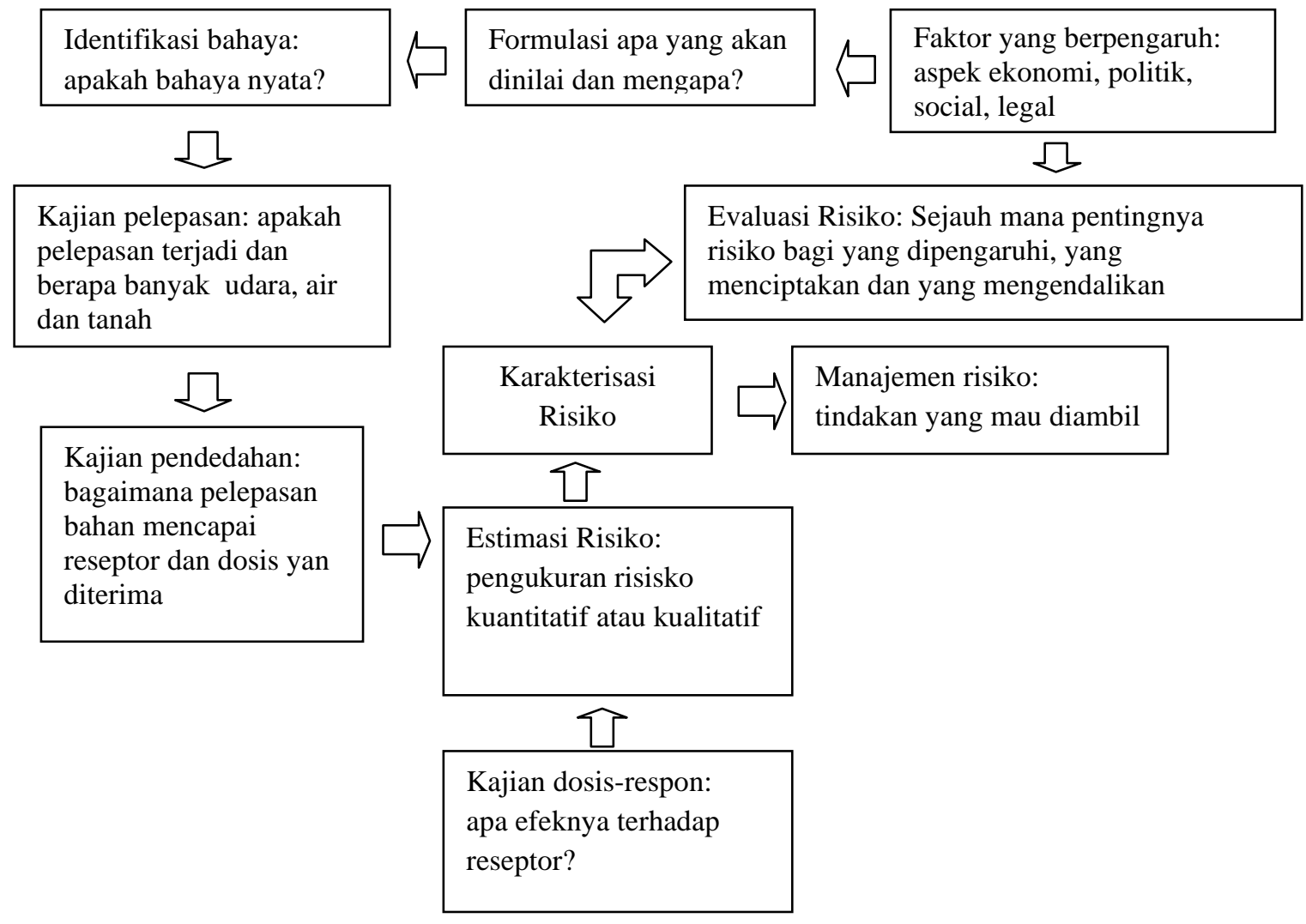

Gambar 1. Elemen-elemen Kajian Risiko Lingkungan

Identifikasi bahaya dalam kajian risiko lingkungan memerlukan penetapan agen-agen yang dapat menyebabkan kerusakan pada penerima baik manusia, organisme tertentu, atau suatu ekosistem. Identifikasi juga dilakukan dengan langkah terbalik untuk mengidentifikasi bagaimana kerusakan dapat terjadi. Identifikasi bahaya dapat dikaitkan dengan tahap lain dari kajian risiko misalnya analisis pelepasan (release analysis). Metode yang digunakan untuk mengidentifikasi bahaya ditetapkan melalui sifat alamiah bahaya dan melibatkan uji toksikologi, penilaian kegagalan dan laju kecelakaan serta studi epidemologi.

Kajian pelepasan (release assessment) melibatkan identifikasi potensi sumber risiko untuk melepaskan agen berbahaya ke lingkungan. Hal ini dapat secara deskriptif atau mengkuantifikasi pelepasan. Kajian pelepasan memerlukan pendeskripsian jenis, jumlah, waktu dan kemungkinan pelepasan bahaya ke dalam lingkungan serta mendeskripsikan perubahan-perubahan yang mungkin terjadi akibat berbagai aksi atau kejadian.Ketiga hal tersebut (Formulasi Masalah, Identifikasi Bahaya dan Kajian Pelepasan) merupakan tahap seleksi. Berdasarkan hal tersebut ditetapkan apakah kajian risiko diperlukan atau tidak. Proses seleksi yang hampir mirip juga ada dalam Guideline on Ecological Risk Assessment, National Environment Protection, Australia (1999). Setelah semua data mendukung untuk dilakukan kajian risiko maka kajian risiko lingkungan dilanjutkan ke tahapan berikut: Kajian pendedahan (exposure assessment) terdiri dari deskripsi dan kuantifikasi kondisi dan sifat yang relevan dari pendedahan ke manusia atau lingkungan oleh bahaya yang diproduksi atau dilepas oleh sumber risiko tertentu. Kajian pendedahan memerlukan deskripsi intensitas, frekuensi, dan lama pendedahan melalui berbagai media, rute pendedahan, dan sifat alamiah populasi yang terdedah.

Kajian akibat atau kajian dosis-respon (consequence assessment or dose-response assessment) mengkaji akibat dari pelepasan atau produksi bahaya ke populasi tertentu, kuantifikasi hubungan antara pendedahan dan bahaya serta terhadap kesehatan dan lingkungan akibat pendedahan tersebut. Penilaian akibat terhadap kesehatan manusia biasanya adalah mortalitas dan morbiditas, sedangkan terhadap sistem ekologis biasanya lebih bervariasi dan cukup sedikit sasaran akhir yang berhasil didefinisikan. Data kajian akibat didasarkan pada uji toksisitas dan ekotoksisitas, epidemologi dan modeling misalnya model dosis-respon.

Estimasi risiko (risk estimation) mengintegrasikan hasil dari kajian pelepasan, kajian pendedahan dan kajian akibat yang akan menghasilkan risiko terhadap kesehatan dan ekologi yang terukur.

Evaluasi risiko menilai apakah kajian risiko dalam prakteknya memiliki arti atau tidak. Hal ini meliputi pengakuan terhadap persepsi masyarakat terhadap risiko serta pengaruhnya terhadap kemampuan masyarakat menerima risiko dan keputusan risiko. Evaluasi risiko juga memasukkan unsur pemahaman terhadap risiko dan manfaat serta menggunakan isu tersebut dalam finalisasi kajian risiko.

Karakterisasi risiko merupakan hasil integrasi evaluasi dan pendugaan risiko. Dalam beberapa kajian risiko lingkungan, evaluasi risiko diabaikan karena sifat alamiahnya yang "tidak berlandaskan bukti empiris/ilmiah", meskipun pandangan tersebut banyak juga ditentang. 


\section{KAJIAN RISIKO AGEN HAYATI UNTUK PERTANIAN}

Hingga saat ini belum ada pedoman dan prosedur untuk melakukan kajian risiko terhadap agen hayati yang digunakan untuk pertanian. Di dunia internasional, beberapa dokumen telah dihasilkan terkait dengan impor dan pelepasan agen hayati untuk pertanian terutama untuk agen pengendalian hayati invertebrata (invertebrate biological control agents/IBCAs) misalnya regulasi yang dikeluarkan oleh organisasi pertanian dunia (FAO, 1996; 2005), organisasi perlindungan tanaman mediterania dan eropa (EPPO, 1999; 2001; 2002) dan organisasi kerjasama ekonomi dan pembangunan (OECD, 2004). Pedoman untuk penggunaan skala luas pupuk hayati juga telah lama dikeluarkan oleh OECD (OECD, 1995).

Tujuan dari berbagai regulasi internasional tersebut adalah untuk menyediakan pedoman bagi pemohon serta Otoritas Nasional yang kompeten untuk menyediakan informasi yang diperlukan untuk melakukan kajian risiko terkait dengan impor dan penggunaan agen hayati untuk pertanian (Bigler et al., 2005 ; OECD, 1995).

Pentahapan kajian risiko agen hayati untuk pertanian secara umum mengikuti pentahapan kajian risiko yang telah diuraikan pada Bab II. Pada Bab III berikut ini diuraikan secara spesifik mengenai kajian risiko Agen Pengendali Hayati Invertebrata dan kajian risiko untuk Mikroorganisme yang Digunakan sebagai Pupuk Hayati dan Proteksi Tanaman. Setiap pentahapan dalam kajian risiko tidak diulas secara rinci tetapi ulasan lebih ditekankan berdasarkan sifat dan karakterisasi organisme sasaran.

\subsection{Kajian Risiko Agen Pengendali Hayati Invertebrata Asing}

Agen pengendali hayati invertebrata (IBCA) merupakan penyebutan untuk insekta, rayap (mites) dan nematoda yang digunakan sebagai agen untuk perlindungan tanaman (Bigler et al., 2005). Di Eropa otoritas nasional yang kompeten (Competent National Authorities) melakukan pengaturan impor dan pelepasan IBCA yang tidak berasal dari wilayah setempat melalui prosedur dua tahap. Tahap pertama adalah pemberian otoritas impor untuk kandidat IBCA yang digunakan dalam kerangka penelitian. Kandidat IBCA tersebut tidak harus diketahui semua karakteristiknya misalnya persyaratan iklim dan inang IBCA, atau rencana penggunaan IBCA tersebut untuk pengendali hayati. Penelitian dilakukan dalam ruang terkendali (containment) untuk menjawab beberapa pertanyaan penelitian terkait. Pada tahap ini, risiko lingkungan tidak akan mampu dijawab dengan memadai. Bila kandidat IBCA telah dikenal dan pernah dilepas di wilayah bersangkutan maka peraturan yang diterapkan akan berbeda. Pada kasus tersebut sebagian besar data dan informasi untuk melakukan kajian risiko lingkungan kemungkinan telah tersedia dan risiko dapat dievaluasi dengan lebih akurat. Jika pelepasan dalam skala penelitian akan dilakukan, maka harus dilakukan kajian risiko dengan ketat karena konsekuensi yang tidak diharapkan terhadap lingkungan dapat bersifat tidak dapat balik dan tidak tergantung besar kecilnya skala pelepasan.
Tahap kedua adalah perijinan untuk pelepasan IBCA yang digunakan untuk pengendali hayati model klasik atau perijinan pemasaran untuk pelepasan inundatif/inokulatif (inundative/inoculative release). Persyaratan untuk proses perijinan tersebut lebih ketat daripada untuk penelitian. Pemohon harus menyediakan seluruh informasi sehingga Otoritas Nasional yang kompeten mampu melakukan kajian risiko yang memadai.

\subsubsection{Informasi yang Harus Disediakan Oleh Pemohon untuk Penelitian}

Informasi yang perlu disediakan oleh pemohon meliputi 1) nama dan organisasi pemohon, serta nama personal yang bertanggung jawab. 2) Maksud dan tujuan penelitian terhadap IBCA tersebut dan kegunaannya. 3) Taksonomi dan karakteristik IBCA yang akan dikaji yang meliputi identitas IBCA, asal atau lokasi pengambilan IBCA atau bila berasal dari laboratorium perlu disebutkan laboratorium asal pembiakan, dan bila relevan perlu disediakan informasi mengenai biologi, distribusi, musuh alami, komensalisme, dan kontaminan. 4) Kajian risiko terhadap kesehatan manusia/hewan/tanaman. Semua informasi terkait terhadap kesehatan manusia, hewan dan tanaman harus disediakan misalnya kemungkinan menyebabkan alergi, iritasi, vektor penyakit. 5) Potensi risiko terhadap lingkungan bila terlepas yang meliputi kisaran inang dan organisme bukan target potensial di wilayah kajian, penggunaan IBCA tersebut sebelumnya atau saat ini dalam riset dan pengendalian hayati, meliputi pengaruh lingkungan teramati dan potensi untuk menetap dan menyebar. 6) Fasilitas dan prosedur dengan cara mendeskripsikan bagaimana risiko diidentifikasi, kemungkinan terlepasnya IBCA tersebut ke alam liar serta bagaimana mengendalikannya. 7) Kajian risiko dan kesimpulan melalui review risiko-risiko yang dapat diidentifikasi dan menjustifikasi mengapa level perlindungan yang diterapkan baik untuk transportasi maupun riset memadai.

\subsubsection{Informasi yang Harus Disediakan Oleh Pemohon untuk Pelepasan}

Pemerintah ataupun Otoritas Nasional yang kompeten perlu menetapkan petunjuk praktis yang harus diikuti oleh pemohon sehingga Otoritas Nasional tersebut mampu mengevaluasi risiko dan keuntungan dalam upaya untuk menetapkan apakah permohonan untuk memasarkan atau melepaskan IBCA ke lingkungan dikabulkan, dikabulkan bersyarat atauditolak.

Pada tahap ini IBCA tersebut sebelumnya telah mendapatkan persetujuan dari otoritas yang kompeten untuk importasi dalam kerangka penelitian atau importasi untuk proses pelepasan dan/atau pemasaran. Tahapan ini dibagi untuk IBCA asing yang belum pernah dilepas di wilayah/negara tujuan serta informasi yang dibutuhkan bagi IBCA yang sebelumnya pernah dilepas di areal lainnya dalam kesatuan negara/wilayah yang sama.

Permohonan untuk pelepasan IBCA asing perlu menyertakan berbagai informasi berikut: 1) nama dan alamat pemohon serta personal yang bertanggung jawab. 2) Deskripsi dan tujuan penggunaan meliputi nama dagang, nama ilmiah, metode pasokan dan formulasi, fungsi (misal 
sebagai predator, parasitoid), nama hama yang akan dikendalikan serta tanaman dimana IBCA akan dilepas, lokasi pelepasan, karakteristik khusus, tahap kehidupan ketika dilepaskan, rekomendasi penggunaan, penyimpanan dan apakah akan dilepaskan secara permanen atau tidak. 3) Taksonomi dan karakterisasi meliputi identifikasi dan informasi detil mengenai asal IBCA yang akan dilepaskan. 4) Informasi tentang distribusi organisme tersebut saat ini baik distribusi di dalam lokasi alamiahnya maupun penyebaran baik akibat pelepasan tidak sengaja maupun disengaja. 5) Sifat biologi dan ekologi di area penyebaran yang meliputi deskripsi tentang sifat biologi, mekanisme daya tahan (survival), mekanisme penyebaran, kisaran iklim, kisaran habitat, kisaran inang dan musuh alami/ patogen. 6) Sejarah mengenai penyebaran sebelumnya baik sengaja maupun tidak sengaja serta akibat yang ditimbulkannya. 7) Informasi tambahan yang diperlukan. 8) Kepastian bahwa IBCA tidak membawa kontaminan. 9) Kajian tentang keamanan dan efeknya terhadap kesehatan. 10) Kajian risiko lingkungan yang meliputi wilayah dimana pelepasan akan dilakukan serta variasi regional yang kemungkinan mempengaruhi risiko. Kajian tersebut meliputi juga efikasi dan manfaat ekonomis.

Persyaratan untuk IBCA yang sebelumnya pernah dilepaskan sebelumnya di wilayah sebelumnya relatif lebih sederhana. Bila IBCA yang pernah dilepas di wilayah yang bersangkutan dan tidak menimbulkan efek yang merugikan maka aplikasi diperlukan untuk memperbaharui ijin. Berdasarkan alasan hak kekayaan intelektual atau kerahasiaan komersial maka permohonan ijin yang lengkap diperlukan bagi pemohon kedua atau selanjutnya.

\subsection{Kajian Risiko Agen Pengendali Hayati Invertebrata Lokal}

Di Eropa maupun beberapa peraturan internasional, rencana pelepasan inundatif/inokulatif ataupun komersialiasi agen pengendali hayati invertebrata lokal juga memerlukan kajian risiko untuk memastikan bahwa agen tersebut tidak menimbulkan dampak negatif bagi lingkungan. Dalam kerangka untuk mendapatkan ijin, pemohon perlu melampirkan berbagai informasi berikut: 1) nama dan alamat pemohon serta orang yang bertanggung jawab, 2) tujuan penggunaan serta manfaat potensial, 3) taknomomi dan karakterisasi, 4) memastikan bahwa IBCA tersebut berada dalam daftar spesies yang diteliti aman untuk digunakan di wilayah pelepasan. Bila memenuhi persyaratan tersebut maka tidak perlu ada pertanyaan lain yang perlu dijawab.

Bila spesies tersebut tidak terdapat dalam daftar spesies yang dikatagorikan aman untuk dilepaskan maka diperlukan informasi lanjut yang meliputi: 5) distribusi geografis IBCA, 6) kajian risiko terhadap manusia/ binatang/tanaman, 7) risiko potensial terhadap lingkungan, kajian dan manajemen risiko, 8) efikasi IBCA dalam mengendalikan spesies target serta manfaat ekonomi pelepasan.

\subsection{Kajian Risiko Pelepasan Mikroorganisme untuk Pupuk Hayati dan Proteksi Tanaman}

Berbeda dengan penggunaan invertebrata untuk pengendali hayati, pedoman untuk pelepasan mikro- organisme untuk pupuk hayati dan proteksi tanaman masih cukup sedikit diantaranya adalah yang dikeluarkan oleh organisasi kerjasama ekonomi dan pembangunan (OECD, 1995). Hingga saat ini belum ada tatacara yang baku sebagaimana pelepasan IBCA. Dengan demikian pedoman untuk kajian risiko pelepasan mikroorganisme untuk pupuk hayati dan proteksi tanaman masih perlu dikembangkan lebih lanjut. OECD, misalnya, menggunakan konsep familiaritas (familiarity) untuk mengembangkan prinsip kajian risiko lingkungan untuk pupuk hayati.

\subsubsection{Konsep Familiaritas}

Konsep familiaritas merupakan suatu hal yang dinamis yang akan semakin membaik dengan meningkatnya pengalaman dan pengetahuan. Familiaritas memudahkan untuk memprediksi potensi pengaruh negatif introduksi pupuk hayati. Contohnya adalah pengetahuan dan pengalaman dalam menggunakan mikroorgansime yang mirip atau penggunaan mikroorganisme yang baru dalam lingkungan yang sama atau mirip. Informasi yang berguna juga dapat diperoleh dari kajian rumah kaca, kajian mikrokosmos dan percobaan lapang terbatas.

\section{Familiaritas dengan Mikroorganisme}

Terdapat sejarah panjang tentang keamanan penggunaan beberapa pupuk hayati terutama rhizobia. Informasi historis tentang pemanfaatan pupuk hayati akan menjadi hal penting untuk galur mikroorganisme yang mirip lainnya yang akan digunakan sebagai pupuk hayati. Dengan demikian tingkat familiaritas akan tergantung jenis mikroorganisme yang akan dilepaskan ke lingkungan.

\section{Familiaritas dengan Interaksi Mikrob-Tanaman}

Hubungan timbal balik antara beberapa pupuk hayati dan tanaman inangnya telah banyak diketahui. Hal ini terutama benar untuk asosiasi rhizobia-legum dan interaksi cendawan mikoriza. Sekalipun mekanisme yang sebenarnya tentang bagaimana suatu mikroorganisme mampu meningkatkan pertumbuhan tanaman tidak diketahui dengan pasti masih tetap terdapat familiaritas terkait dengan ekologi interaksi mikrob-tanaman. Idealnya tingkat familiaritas seperti respon tanaman terhadap inokulasi pupuk hayati tertentu dapat diprediksi dalam kondisi yang diketahui. Akan tetapi hubungan tersebut seringkali kompleks dan mudah terganggu akibat perubahan kondisi lingkungan. Penggunaan inokulan ganda menunjukkan pentingnya pemahaman tentang familiaritas untuk mengkaji interaksi antar mikroorganisme dan mikroorganisme dengan tanaman.

\section{Familiaritas dan Lingkungan}

Familiaritas dnegan lingkungan meliputi familiaritas dengan berbagai kisaran inang baik tanaman maupun hewan dan habitat, termasuk tumbuhan liar yang dikolonisasi oleh pupuk hayati tersebut. Bila kajian risiko dilakukan maka beberapa aspek terkait dengan habitat alamiah harus menjadi bahan pertimbangan. Bila suatu mikroorganisme diisolasi dari suatu tempat tertentu dan dikembalikan ke tempat tersebut, tanpa mengalami perubahan, untuk pengujiannya sebagai inokulan, maka level risiko akan minimal selama mikroorganisme tersebut 
tergolong bukan patogen. Bila mikroorganisme tersebut akan digunakan di habitat yang bukan aslinya maka penting untuk mempertimbangkan potensinya menimbulkan dampak negatif bagi lingkungan.

\section{Penerapan Konsep Familiaritas}

Konsep familiaritas dapat digunakan untuk menilai risiko mikroorganisme yang digunakan baik sebagai pupuk hayati maupun proteksi tanaman. Familiaritas tidak berarti sama dengan keamanan. Informasi tentang familiaritas digunakan untuk menganalisis potensi merugikan dari suatu mikroorganisme yang akan dilepas ke lingkungan. Konsep tersebut membantu untuk memutuskan apakah informasi memadai untuk menetapkan apakah bahaya (hazard) ada, dan bila ada, apakah pendedahan belum mencukupi untuk menyebabkan peningkatan risiko.

Bila informasi tidak memadai, misalnya tingkat ketidak-familiaritas untuk menetapkan suatu keputusan terlalu besar, atau bila dipertimbangkan bahwa peningkatan risiko mungkin terjadi maka manajemen risiko perlu dilakukan. Konsep familiaritas dapat juga digunakan misalnya untuk menyeleksi stragegi manajemen risiko yang tepat.

\subsubsection{Kajian Risiko Pelepasan Mikroorganisme}

Konsep familiaritas sebagaimana yang telah diuraikan merupakan hal utama dalam seluruh fase kajian dan evaluasi. Mikroorganisme baik yang digunakan sebagai pupk hayati maupun proteksi tanaman memiliki sifat biologi intrinsik yang perlu dipertimbangkan dalam mengidentifikasi potensi merugikan dan untuk menilai risiko. Level risiko ditetapkan dengan mempertimbangkan potensi dan besarnya pengaruh merugikan melalui kajian level pendedahan dan kemungkinan frekuensi terjadinya efek merugikan.

Kajian risiko meliputi beberapa hal berikut: 1) Pendedahan. Pendedahan perlu mempertimbangkan berbagai hal berikut yaitu daya hidup (survival), persistensi dan penyebaran. 2) Scale-up. Petimbangan tentang scale-up diperlukan untuk menguji validitas asumsi yang disusun atau kesimpulan yang diambil selama percobaan skala laboratorium, rumah kaca dan lapang terbatas. Hal ini merupakan tahap yang penting dalam pengembangan untuk komersialisasi produk. 3) Potensi pengaruh melalui identifikasi kemungkinan pengaruh merugikan berdasarkan familiaritas dengan mikroorganisme dan lingkungan akan menentukan tingkat risiko. Tidak semua pengaruh adalah merugikan, tetapi tergantung kombinasi dengan terjadinya peningkatan pendedahan yang akan menghasilkan peningkatan risiko. 4). Kontaminan inokulan. Inokulan yang akan digunakan sebagai pupuk hayati maupun agen proteksi tanaman dapat mengandung organisme kontaminan yang dapat menyebabkan pengaruh merugikan. 5) Inokulan campuran. Pupuk hayati atau agen proteksi tanaman bisa mengandung lebih dari satu jenis mikroorganisme. Penggunaan inokulum campuran tersebut perlu dikaji untuk mengetahui interaksi antar mikroorganisme penyusun dan antar mikroorganisme dan tanaman.

\section{KESIMPULAN}

Kajian risiko lingkungan untuk agen hayati yang digunakan dalam bidang pertanian perlu dilakukan untuk meminimumkan dampak negatif yang mungkin timbul akibat pelepasan agen hayati tersebut ke lingkungan. Kajian risiko tersebut juga berguna untuk melakukan manajemen risiko bila potensi efek merugikan akibat pelepasan agen hayati tersebut ada. Hingga saat ini di Indonesia belum ada pedoman yang bisa digunakan baik oleh peneliti maupun pihak industri yang ingin mengimpor dan/atau melepaskan agen hayati di Indonesia. Beberapa pedoman baik yang berlaku di Eropa maupun yang disusun oleh berbagai lembaga internasional dapat digunakan sebagai contoh dan pendekatan untuk menyusun pedoman yang mirip dan sesuai dengan kebutuhan di Indonesia.

\section{DAFTAR PUSTAKA}

Bigler, F., Bale, J.S., Cock, M.J.W., Dreyer, H., Greatrex, R., Kuhlmann, U., Loonmans, A.J.M., and van Lenteren, J.C. 2005. Guidelines on information requirements for import and release of invertebrate biological control agents in European countries. Biocontrol News Inform. 26:115N-123N.

EEA. 1998. Environmental Risk Assessment. European Environmental Agency.

EPPO. 1999. Safe use of biological control: first import of biological control agents for research under contained conditions. EPPO Standard PM6/1(1). EPPO Bulletin, 29:271-272.

EPPO. 2001. Safe use of biological control: import and release of biological control agents. EPPO Standard PM6/2(1). EPPO Bulletin, 31:33-35.

EPPO. 1999. List of biological control agents widely used in the EPPO region. EPPO Standard PM6/3(2). EPPO Bulletin, 32:447-461.

FAO. 1996. Code of conduct for the import and release of exotic biological control agents. International Standard for Phytosanitary Measures No. 3. Secretariat of the International Plant Protection Convention, FAO, Rome.

FAO. 2005. Guidelines for the export, shipment, import and release of biological control agents and other beneficial organisms. International Standard for Phytosanitary Measures No. 3. Secretariat of the International Plant Protection Convention, FAO, Rome.

Foster, K., Vecchia, P., and Repacholi, M. 2000. Science and the precautionary principle. Science p. $979-981$, May 12.Hilbeck A. and Andow, D.A (Eds.). 2004. Environmental Risk Assessment of Benefically Modified Organisms. A Case Study of Bt Maize in Kenya. CABI Publishing, Walling ford, UK.

Hilbeck A, Andow, D.A and Fontes, E.M.G. (Eds.). 2006. Environmental Risk Assessment of Benefically 
Modified Organisms. Methodologies for Assessing Bt Cotton in Brazil. CABI Publishing, Walling ford, UK.

Mentan, 2009. Peraturan Menteri Pertanian Tentang Pupuk Organik, Pupuk Hayati dan Pembenah Tanah. No. 28/PERMENTAN/SR.130/5/2009.

NEP. 1999. Guideline on Ecological Risk Assessment, National Environment Protection, Australia.

OECD. 1995. Safety considerations for biotechnology, scale-up of micro-organisms as biofertilizers. Organization for Economic Co-operation and Development, 63 pp.
OECD. 2004. Guidance for information requirements for regulation of invertebrates as biological control agents (IBCAs). Series on Pesticides No. 21, OECD Environment Directorate, 22 pp.

Peraturan Pemerintah. 2005. Peraturan Pemerintah No. 21 Tentang Keamanan Hayati Produk Rekayasa Genetik.

SEPA. 2006. Environmental Risk Assessment Manual. Scottish Environment Protection Agency, SEPA.

U.S. EPA. 2004. Risk Assessment Principles and Practice. U.S. Environmental Protection Agency.

US EPA. 1998. Guidance for Ecological Risk Assessment. US Environmental Protection Agency. 